\title{
Cultural Interpretation of the Pursuit of Happyness
}

\author{
Ren Junhong \\ English Department North China Electric Power University Baoding Hebei Province China \\ rjh1003@126.com
}

\begin{abstract}
The pursuit of happyness, adapted from a true story, tells how Chris Gardner grows from a salesperson to a successful stock broker and finally starts his own business. This movie well illustrates the American Dream and gives insights into American characters, from which western outlooks on life and values are given full display. This paper explores the cultural perspective of Chris Gardner's Afro-Americans' American dream from the aspects of individualism and equality.
\end{abstract}

Index Terms - the Pursuit of Happyness, Chris Gardner, American dream, individualism, equality

\section{Introduction}

The Pursuit of Happyness, adapted from the story of Chris Gardner, an African American investment specialist, successfully interprets how a broken salesperson, a responsible single father, on the brink of bankruptcy, struggles to become a stock trader and eventually make a famous financial investor of himself. The film was directed by the Italy director Gabriel Muccino and starred by Will Smith. It won the Oscar nomination in 2006.

Chris Gardiner was a salesman; he was on-the-go every day, selling bone density scanners to large hospitals to sustain his family. Without higher education, he could not secure a desirable job and lived a life of extreme poverty. This miserable economic crisis exhausted the conjugal relation and led to his wife's departure to New York. Meanwhile, Chris Gardiner and his son were driven out of their rental place homeless since they could not afford to pay the rent. When he accidentally learned that being skillful at digital numbers and interpersonal relationships would enable a person to land a job as a stock broker, he took the initiative to pay a visit to Jay Twistle, the Victor securities manager. By virtue of his dedication, strong sense of humor, and witty answers, as well as a small cube, he seized the opportunity to do internship in a company, with no salary and only $1 / 20$ chance of being recruited though. In the six months of internship that followed, despite the severe poverty, he never shook his faith to move forward. At the end of the internship period, to his great joy, he stood out from other trainees and attained the job as a stock broker, and years later set up his own company.

As is known, films record and reveal the essence and attributes of a culture and enhance people's understandings on it [1]. American films, as an influential part in the world of films, unfold before us many aspects of American culture, among which the pursuit of happyness well illustrates the American core values and can well be said to be a microcosm of American dreams, individualism, and equality.

\section{A Glimpse of American Dreams in the Pursuit of Happyness}

American dreams took shape along with the foundation of the United States. Ever since the Declaration of Independence in 1776, American dreams have inspired generations of Americans and immigrants alike to lead a prosperous life by labor, courage, determination and unremitting efforts, rather than relying on a particular social class and assistance from elsewhere, just as what is stated in the Declaration of Independence: all men are created equal. Each is endowed by their Creator with certain unalienable rights, among which are life, liberty and the right to pursue happiness. Or as what is interpreted by Thomas Wolfe on the American dreams, which read "anyone, no matter what his origin is, no matter what his social position is, no matter how rich opportunities endowed by nature, has the right to live, to work, to become the person he wants to be through his own terms." As can be seen above, American dreams involve many different aspects like confidence, independence, individualism, and equality.

In this film, Chris Gardiner's rise to success and wealth could be seen as a course to fulfill his American dream. Despite a salesman of low social status, he was self-reliant, perseverant and resolute to achieve his life goal through unremitting struggles. At the same time, Chris Gardiner, an Afro-American protagonist of the film, also, could be deemed as the representative of all the Afro-Americans. His pursuit of American dreams and happiness is therefore reinvested with new meanings. The theme of the film is, accordingly, more the interpretation of Afro-Americans' American dreams than the simple American dreams.

\subsection{A glimpse of Individualism from Chris Gardner}

Individualism is the essence of American culture. It sprouted in Italian Renaissance movement in the $14^{\text {th }}$ Century, was spread in the French Enlightenment in $18^{\text {th }}$ Century, and borne fruit in the United States. As an individual-oriented philosophy of life, individualism claims that everyone has his value and freedom for self-fulfillment. Individualism has been deeply rooted in American characters. Generally speaking, Americans are self-centered, and have the pursuit of happiness the common goal toward life. Thanks to individualism, personal strivings and individualistic principles have become vital parts of American culture, and the pursuit of personal interests and personal autonomy has been endowed with divine meanings in America [2]. Just as Professor Hu (1992) once pointed out, one cannot understand American behaviors without knowledge about the American individualism. 
In consequence, individualism is highly advocated in American films, the Pursuit of Happyness being no exception. In this movie, Chris Gardner gives full display of individualism. To start with, he is industrious, independent and self-reliant. Though starting from scratch, he did not yield to sorts of hardships and finally became the famous financier. In him, we can perceive one of Americans' good qualities--hard-working spirits. For ordinary Americans, work is something they must take seriously since it is not only a means to achieve good social conditions, but also a duty they must perform. As long as one work hard, they believe, he will win his day and master his own destiny. This manifests itself in the fact that they are very concerned about his attitude towards work and work achievements when assessing a person. In addition, Chris Gardiner is optimistic and confident. Reflecting on the past, he once noted: in my twenties, I experienced all kinds of hardship and scary moment people can hardly imagine, but I never gave up. In the six months of unpaid internships, for instance, he kept constantly on the run every day, commuting between his work place and hospitals, trying to sell scanners in order to feed him and his son; he took his son to live upon the streets, between shelters, in the park, in the lavatory of train stations, or under the office desk. Be that it may, instead of surrendering in the face of such horrible financial crisis, however, he embraced the adversities and survived. As we all know, America is a rather young country, with only more than 200 years of history behind her. By virtue of this fact, Americans are neither obsessed with the past, nor satisfied with the status quo, but willing to look to the future. They are open-minded, ready to meet the challenges that may get in their way. Last but not least, Chris Gardiner yearns for success and personal happiness. Success is the essence and the ultimate embodiment of American dreams [3]. Although Chris Gardiner was not well-educated, the vision of a better future motivated him to stand up to the reality, and not draw back in the presence of adversities. "If you have a dream, you gotta protect it," he once stated. His dream to establish himself drove him to break open a way through brambles and thorns. In the meantime, his persistence, wisdom and courage made possible his successful transformation from a salesperson into a stock broker.

\subsection{A glimpse of Equality in the Pursuit of Happyness}

Equality is one of the most important aspects of democratic thoughts in the Declaration of Independence. It inherited from and further developed Pock's natural rights theory, which claims that all men are created equal, endowed with the unalienable rights to pursue life, liberty and happiness. One of the most important aspects of equality in American culture is racial equality.

Racial issue has been a long-standing problem in America. From the civil war to Martin Luther King's "I have a dream", and then to the black Secretary of the State and the black President, the Afro-Americans have never ceased their efforts for racial equality in American history. In accordance with that, racial equality holds still as an important topic in the course of development of America films. Nowadays, the white, and the black likewise, have become an indispensable force of American society. This point can be manifested either from the characters in the films or from the Afro-American actors [1].

In this film, Chris Gardiner can be viewed as a representative of Afro-Americans. He was constantly seeking his dream. "You got a dream, you gotta protect it. People can't do something themselves, they wanna tell you you can't do it. If you want something, go get it." This dream backed him up to get through even if when he was at his worst. Because, he believed, his efforts would be paid one day and everything would turn for the better. From Chris Gardiner, we can see the charm of American dream still lies in its fulfillment. Just as Afro-Americans play an indispensible part in American society, so do their dreams to the American Dreams. The issue of whether or not Afro-American dreams can be achieved has, to some extent, become an important standard to measure the American social development and civilization progress [4]. After all, A65fro-Americans belong to no other country but America [5].

\section{Conclusion}

The Pursuit of Happyness tells the story of how Chris Gardiner rose up to wealth and upper class. As a representative of Afro-Americans, his self-reliance, optimism, self-confidence, and hard-working spirits well reflect the character of Americans; his successful story embodies the American cultural connotation of individualism, equality and American dreams. This film passes on to us the message that the Afro-Americans could also, through unremitting efforts, reach out to their dreams and share equality, freedom, democracy with the white.

A film is the carrier of culture, in order to understand what is intended to be conveyed in a film, therefore, it is advisable that we learn about the relevant cultural background.

\section{References}

[1] Zhang, X. \& Liu, Y.Q. The Embodiment of Western Culture in American Movies. Movie Literature, 2010 (20).

[2] Li, Y.M. \& Xu, J.G. Probing Into the Cultural Elements of American Movies. Movie Literature, p10, 2008 (10).

[3] Ai,Q. \& Yang,X. On Cultural Connotation of American Dream from American Movies. Journal of Suzhou College, 2010 (3).

[4] Yuan, S.Y. Afro-American's American Dream Under Racial Discrimination. Mangzhong Literature, 2012 (7).

[5] James Baldwin. The Fire Next Time. Dial Press, 1963. 